\title{
MENINGKATKAN KEMAMPUAN GURU DALAM MERANCANG DAN MELAKSANAKAN KEGIATAN BELAJAR-MENGAJAR MELALUI PELAKSANAAN SUPERVISI KLINIS
}

\author{
Ecin Kuraesin \\ SD Negeri 3 Picungremuk, Jl. Syekh Abdul Muhyi Picungremuk, Kawalu, Tasikmalaya, Indonesia \\ Email: aennaen3307@gmail.com
}

\begin{abstract}
Teacher professional development needs to be done in the form of increasing their competence / ability in the field of managing the learning process, utilizing learning resources that can be done through professional education, training, workshops, seminars, scientific activities, MGMP, and supervision. Supervision is the provision of assistance to teachers to overcome difficulties in carrying out their teaching duties and improve their abilities in teaching and learning activities in class. The purpose of this research is to improve the ability of teachers to design and implement teaching and learning activities through the implementation of clinical supervision. The method used in this research is action research method. This research was conducted at SD Negeri 3 Picungremuk with the object of research, namely 10 teachers conducted in August 2019. The results showed: 1) The ability of teachers in preparing lesson plans was still not optimal; 2) The results of observations in cycle II indicate an increase / improvement in the ability of teachers both in preparing lesson plans and in implementing them in the classroom. The difficulties encountered in the first cycle can be overcome and 3) The implementation of clinical supervision can improve the ability of teachers to compile and plan lessons.
\end{abstract}

Keywords: Supervision, Teacher's Teaching and Learning Ability

\begin{abstract}
ABSTRAK
Pengembangan keprofesionalan guru perlu dilakukan dalam bentuk peningkatan kompetensi/kemampuan mereka dalam bidang pengelolaan proses pembelajaran, pemanfaatan sumber belajar yang dapat dilakukan melalui pendidikan profesi, pelatihan, workshop, seminar, kegiatan ilmiah, MGMP, dan supervisi. Supervisi adalah pemberian bantuan kepada guru untuk mengatasi kesulitan dalam melaksanakan tugas mengajarnya dan meningkatkan kemampuannya dalam kegiatan belajar mengajar di kelas. Tujuan dari penelitian ini adalah meningkatkan kemampuan guru dalam merancang dan melaksanakan kegiatan belajar-mengajar melalui pelaksanaan supervisi klinis. Metode yang digunakan dalam penelitian ini adalah metode penelitian tindakan (action research). Penelitian ini dilakukan di SD Negeri 3 Picungremuk dengan objek penelitian yaitu guru yang berjumlah 10 orang yang dilakukan pada bulan Agustus 2019. Hasil penelitian menunjukkan: 1) Kemampuan guru dalam menyusun RPP masih belum optimal; 2)Hasil pengamatan pada siklus II menunjukkan adanya peningkatan/ perbaikan kemampuan guru baik dalam menyusun RPP maupun dalam pelaksanaannya di kelas. Kesulitan- kesulitan yang dijumpai pada siklus I sudah dapat diatasi dan 3)Pelaksanaan supervisi klinis dapat meningkatkan kemampuan guru dalam menyusun dan merencanakan pembelajaran.
\end{abstract}

Kata Kunci: Supervisi, Kemampuan Belajar Mengajar Guru

Cara sitasi: Kuraesin, E. (2021). Meningkatkan Kemampuan Guru dalam Merancang dan Melaksanakan Kegiatan Belajar-Mengajar melalui Pelaksanaan Supervisi Klinis di SD Negeri 3 Picungremuk. J-KIP (Jurnal Keguruan dan IImu Pendidikan), 2 (1), 99-104. 


\section{PENDAHULUAN}

Pendidikan merupakan hal penting dalam rangka meningkatkan kualitas Sumber Daya Manusia baik dari segi spiritual, intelegensi, maupun skill untuk menunjang kehidupannya (Sopiah, 2020). Proses pendidikan formal diawali melalui pendidikan dasar. Artinya bahwa pendidikan dasar merupakan pondasi awal secara formal dan tiap sumber daya manusia mengalami proses pendidikan. Hal tersebut sebagaimana dituangkan dalam Undang-Undang Sistem Pendidikan Nasional Nomor 20 Tahun 2003 Pasal 17 ayat (1) yaitu : "Pendidikan dasar merupakan jenjang pendidikan yang melandasi jenjang pendidikan menengah".

Salah satu permasalahan yang ada pada bidang pendidikan adalah keberhasilan kegiatan belajar mengajar yang dipengaruhi beberapa hal, antara lain keadaan siswa, kemampuan guru dalam mengajar, sarana dan prasarana belajar, dukungan orang tua, dan sebagainya. Guru sebagai salah satu unsur penentu keberhasilan kegiatan belajar mengajar. Kenyataan di lapangan menunjukkan bahwa unjuk kerja (performance) guru dalam melaksanakan kegiatan belajar mengajar sangat bervariasi dan kualifikasi pendidikannya pun beraneka ragam, dan kompetensinya masih belum merata.

Dalam melaksanakan kurikulum guru masih sering mengalami kesulitan karena kurangnya pengetahuan guru tentang kurikulum itu sendiri serta karena beratnya beban tugas lain selain mengajar. Dalam kegiatan belajar mengajar guru memegang peranan yang cukup penting baik dalam perencanaan maupun pelaksanaan kurikulum (Mulyasa, 2006). Guru adalah perencana, pelaksana dan pengembang kurikulum bagi mata pelajaran yang menjadi tanggung jawabnya, terutama pada saat diberlakukannya Kurikulum Tingkat Satuan Pendidikan (KTSP). Untuk melaksanakan KTSP guru harus membuat perencanaan. Perencanaan yang dibuat oleh guru berupa Program tahunan, program semester, dan rencana pelaksanaan pembelajaran (RPP).

Rencana pelaksanaan pembelajaran (RPP) adalah rencana yang menggambarkan prosedur dan pengorganisasian pembelajaran untuk mencapai satu kompetensi dasar yang ditetapkan dalam Standar Isi dan dijabarkan dalam silabus. Rencana pelaksanaan pembelajaran (RPP) harus dibuat oleh guru sebelum mengajar. Agar guru dapat menyusun RPP dan melaksanakannya di kelas, maka guru dituntut memiliki kemampuan atau kompetensi untuk itu. Sesuai dengan UU No. 14 Tahun 2005 pasal 10 guru dituntut memiliki kompetensi pedagogik, kompetensi kepribadian, kompetensi sosial, dan kompetensi professional (Yamin, 2006).

Pengembangan keprofesionalan guru perlu dilakukan dalam bentuk peningkatan kompetensi/kemampuan mereka dalam bidang pengelolaan proses pembelajaran, pemanfaatan sumber belajar yang dapat dilakukan melalui pendidikan profesi, pelatihan, workshop, seminar, kegiatan ilmiah, MGMP, dan supervisi. Supervisi adalah pemberian bantuan kepada guru untuk mengatasi kesulitan dalam melaksanakan tugas mengajarnya dan meningkatkan kemampuannya dalam kegiatan belajar mengajar di kelas (Sahertian, 2008). Supervisi dapat dilakukan oleh kepala sekolah atau pengawas sekolah.

Supervisi dilakukan bukan untuk mencari-cari kesalahan guru tetapi untuk melihat apakah guru mengalami kesulitan dalam mengajar. Apabila ditemukan adanya kesulitan maka pengawas/kepala sekolah sebagai supervisor akan memberikan bantuan untuk mengatasinya. Supervisi klinis adalah suatu proses bimbingan yang bertujuan untuk membantu pengembangan profesional guru/calon guru, khususnya dalam penampilan mengajar, berdasarkan observasi dan analisis data secara teliti dan obyektif sebagai pegangan untuk perubahan tingkah laku mengajar tersebut (Purwanto, 2006).

Berdasarkan uraian tersebut, maka rumusan masalah pada penelitian ini adalah:

a. Bagaimana kemampuan guru dalam menyusun RPP

b. Adakah peningkatan/ perbaikan kemampuan guru baik dalam menyusun RPP maupun dalam pelaksanaannya di kelas? 


\section{METODE PENELITIAN}

Jenis penelitian ini adalah Penelitian Tindakan Kelas (PTK). Penelitian tindakan kelas yang digunakan dalam penelitian ini mengacu pada Model Kemmis \& McTaggrat yang terdiri dari empat komponen, yaitu perencanaan (planning), tindakan (acting), pengamatan (observing) dan refleksi (reflecting). Penelitian ini dilakukan di SD Negeri 3 Picungremuk Kota Tasikmalaya dengan objek penelitian yaitu guru yang berjumlah 10 orang. Waktu pelaksanaan penelitian pada bulan Agustus Tahun Pelajaran 2018/2019, yang dimulai dari tahap orientasi, tahap pengumpulan data, tahap pengolahan data sampai pada laporan hasil penelitian.

\section{HASIL DAN PEMBAHASAN}

Berdasarkan pengamatan supervisor maupun hasil refleksi pada siklus I masih ditemukan kesulitan yang dihadapi guru, baik dalam penyusunan RPP maupun pelaksanaannya di kelas, dan temuan-temuan tersebut disampaikan dan dijelaskan supervisor pada saat pertemuan penyusunan perencanaan untuk siklus II agar pada siklus II kesulitan dan temuan tersebut tidak terjadi lagi.

Penjelasan yang diberikan pada pertemuan perencaan untuk siklus II tanggal 1 Agustus 2019 sebagai berikut:

1. Secara umum yang direncanakan guru dalam RPP belum sepenuhnya dilaksanakan di kelas. RPP merupakan perencanaan pembelajaran yang akan dilaksanakan di kelas, merupakan skenario kegiatan yang akan dilakukan. Pembelajaran di kelas harus sesuai dengan langkahlangkah dalam RPP. RPP harus rinci agar apa yang ada dalam RPP bisa dilaksanakan oleh guru lain apabila guru yang bersangkutan tidak dapat melaksanakan tugas karena suatu alasan yang bisa diterima. RPP tidak hanya sekedar memenuhi tuntutan administrasi tetapi merupakan tuntatan akademis. RPP yang baik akan mencerminkan suatu keberhasilan yang akan dicapai. Orang bijak mengatakan "rencanakan kerjamu dan kerjakan rencanamu", ini menunjukkan betapa pentingnya suatu perencanaan dan perencanaan merupakan salah satu fungsi manajemen sesuai dengan pendapat Terry (Manullang, 1992) dalam bukunya; "Dasar-dasar Manajemen" mengatakan bahwa fungsi manajemen yang disingkat POAC (Planning, Organizing, Actuating, Controlling), perencanaan, pengorganisasian, pelaksanaan, dan pengendalian atau penilaian.

2. Perumusan indikator kurang operasional. Perumusan indikator harus merupakan kalimat operasional dan rumusan yang ada pada indikator merupakan kegiatan yang bisa diukur melalui kegiatan evaluasi. Indikator yang dirumuskan untuk satu KD dapat dijabarkan menjadi beberapa indikator. Dari indikator yang dirumuskan inilah kita menyusun alat evaluasi untuk mengukur apakah standar kompetensi, kompetensi dasar yang ada telah tercapai apa belum.

3. Pengorganisasian kelas masih kurang. Pengorganisasian kelas merupakan salah satu unsur yang penting dalam rangka melaksanakan pembelajaran yang baik di kelas. Pengorganisasian kelas merupakan pengaturan tempat duduk siswa, pembagian kelompok, dan penciptaan situasi kelas yang nyaman selama pelaksanaan pembelajaran. Pengaturan tempat duduk siswa hendaknya juga memperhatikan siswa yang kurang daya tangkapnya ditempatkan di depan, usahakan tempat duduk yang kosong ada di belakang bukan di depan atau di tengah. Pembagian kelompok pada saat ada tugas kelompok di kelas hendaknya diatur agar siswa yang pandai merata di setiap kelompok agar ada transver ilmu dari siswa yang pandai ke siswa kurang pandai.

4. Kurang adanya motivasi terhadap siswa. Motivasi merupakan unsur penting dalam pembelajaran, siswa harus punya motivasi yang tinggi agar siswa tertarik pada mata pelajaran khususnya matematika yang merupakan pelajaran yang selalu dianggap momok dan pelajaran yang sangat sulit. Kenalkan kepada mereka bahwa matematika merupakan pelajaran yang sangat menarik dan banyak digunakan dalam segala kebutuhan. Ajak para siswa menyukai matematika. Untuk itu perlu ada perasaan senang kepada guru yang mengajarnya melalui 
pendekatan-pendekatan kepada siswa, jangan menimbulkan perasaan seram pada guru yang mengajar. Kalau demikian siswa akan takut pada guru dan benci kepada guru yang akan berakibat pada takut dan benci pada mata pelajaran matematika.

5. Alat evaluasi masih belum sesuai dengan indikator. Aat evaluasi digunakan untuk mengukur sejauh mana kompetensi dasar yang dirinci menjadi indikator-indikator telah dicapai. Agar alat evaluasi dapat mengukur pencapaian indikator, maka alat evaluasinya harus sesuai dengan indikator yang ada. Indikator dirumuskan dengan kalimat oprasional yang merupakan tindakan untuk mencapai sesuatu. Tercapai atau tidak bisa diukur dengan menggunakan alat evaluasi.

6. Topik/tema yang dibicarakan tidak ditulis di papan tulis. Tema/topik yang akan diajarkan sebaiknya ditulis di papan tulis agar siswa mengerti apa yang dibicarakan pada waktu itu.Di samping itu siswa dalam membuat catatan di bukunya ada judul/ topik/ tema sehingga apabila mereka belajar akan tahu apa yang dipelajarinya.

7. Kompetensi dasar tidak disampaikan kepada siswa. Kompetensi dasar perlu disampaikan kepada siswa agar mereka mengetahui arah yang ingin dicapai dalam pembelajaran tersebut sehingga mereka termotipasi untuk ikut aktif mencapai tujuan yang dirumuskan pada kompetensi dasar bahkan akan lebih baik lagi kalau indikator pencapaian juga disampaikan kepada siswa.

8. Apersepsi sebelum menerangkan materi baru kurang berkaitan dengan materi baru.

Apersepsi perlu diterangkan kepada siswa agar siswa ada gambaran hubungan antara materi yang lama dan materi yang baru. Dalam apersepsi guru bisa menjelaskan bahwa sebelum memasuki materi yang baru siswa harus telah mengetahui/memahami materi yang menjadi prasyarat untuk materi berikutnya.

9. Kurang memberikan motivasi kepada siswa.

Motivasi sangat perlu agar siswa lebih bersemangat dalam belajar dan siswa senang mengikuti pelajaran yang diajarkan oleh guru. Besarkan jiwa mereka dan ajak mereka untuk selalu belajar demi masa depan mereka.

10. Pembagian kelompok siswa terlalu banyak sehingga ada siswa yanghanya tergantung pada anggota kelompok lain.Membagi kelompok dalam diskusi kelas hendaknya tidak terlalu banyak anggota kelompoknya, karena jika hal itu teradi maka akan sulit mengontrolnya. Ada kecenderungan anggota kelompok hanya sekedar titip nama kepada kelompoknya. Sebaiknya dalam membagi kelompok dirancang agar semua anggota kelompok ikut aktif dalam diskusi dan mengemukakan pendapatnya. Dengan anggota yang relatif kecil dalam penilaian akan lebih mudah dilakukan. Aktivitas mereka akan terpantau dengan baik. Selain itu perlu diperhatikan adanya pembagian kelompok yang merata antara siswa yang pandai dan siswa yang kurang pandai sehingga akan terjadi tutor sebaya di atara mereka.

11. Evaluasi yang dilakukan guru masih bersifat evaluasi kelompok bukan individu. Penilaian hendaknya tidak hanya penilaian kelompok, tetapi hendaknya juga dilakukan untuk individu. Penilaian kelompok tidak mencerminkan nilai untuk individu karena dalam kelompok sering terjadi anggota kelompok hanya ikut-ikutan pada kelompoknya. Jika nilai kelompok baik tidak berarti nilai individu-individu juga baik, mungkin bahkan nilai individu -individu rendah karena nilai kelompok yang baik diperoleh oleh salah satu anggota kelompok yang sangat pandai. Selain hal tersebut di atas, hasil pengamatan supervisor pada pelaksanaan pembelajaran di kelas ditemukan:

1. Nilai RPP lebih besar dari nilai pelaksanaannya di kelas, ini berarti bahwa apa yang direncanakan guru telah rinci tetapi pelaksanaannya di kelas tidak sesuai dengan RPP (dalam mengajar tidak sesuai dengan RPP).

2. Nilai RPP lebih kecil dari pelaksanaannya di kelas, ini berarti bahwa guru tersebut mengajarnya baik sekali. Apa yang dilakukan lebih dari apa yang direncanakan dalam RPP yang dibuatnya. 
Berdasarkan hasil refleksi dan temuan-temuan pada pada sklus I, maka pada saat penyusunan perencanaan untuk siklus II, supervisor mengajak diskusi dengan para guru tentang bagaimana mengatasi kesulitan-kesulitan yang ada, serta memberikan arahan untuk penyusunan RPP dan pelaksanaanya di kelas untuk siklus II. Hasil pengamatan pada siklus II menunjukkan adanya peningkatan/perbaikan kemampuan guru baik dalam menyusun RPP maupun dalam pelaksanaannya di kelas. Kesulitan-kesulitan yang dijumpai pada siklus I sudah dapat diatasi. Hasil penilaian pada siklus I dan siklus II disajikan pada Tabel 1.

Tabel 1. Hasil penilaian RPP siklus I dan siklus II

\begin{tabular}{ccrr}
\hline No. & Nama & \multicolumn{1}{c}{ Siklus I } & \multicolumn{1}{c}{ Siklus II } \\
\hline 1 & S1 & 2,88 & 3,85 \\
2 & S2 & 2,96 & 3,56 \\
3 & S3 & 3,15 & 3,24 \\
4 & S4 & 2,49 & 3,62 \\
5 & S5 & 2,96 & 3,65 \\
6 & S6 & 3,12 & 3,12 \\
7 & S7 & 3,14 & 3,14 \\
8 & S8 & 2,56 & 3,25 \\
9 & S9 & 2,82 & 3,50 \\
10 & S10 & 2,96 & 3,55 \\
& Rata-rata & $\mathbf{2 , 8 7}$ & $\mathbf{3 , 4 1}$ \\
\hline
\end{tabular}

Dari Tabel 1 jika digambarkan dalam bentuk diagram maka seperti pada Gambar 1.

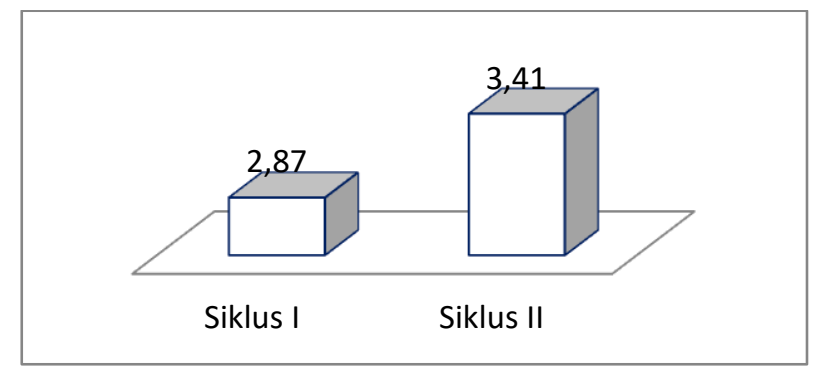

Gambar 1. Hasil penilaian RPP siklus I dan siklus II

Dari Gambar 1 dapat dilihat bahwa telah terjadi kenaikan nilai yang didapat guru dalam penyusunan RPP dari siklus I ke siklus II. Hal ini menunjukkan adanya peningkatan kemampuan guru dalam penyusunan RPP. Sedangkan hasil penilaian terhadap pelaksanaan pembelajaran pada siklus I dan siklus II terlihat pada Tabel 2.

Tabel 2. Hasil penilaian PBM di Kelas siklus I dan siklus II

\begin{tabular}{ccrr}
\hline No. & Nama & Siklus I & \multicolumn{1}{c}{ Siklus II } \\
\hline 1 & S1 & 3,70 & 3,68 \\
2 & S2 & 3,83 & 3,82 \\
3 & S3 & 3,45 & 3,61 \\
4 & S4 & 3,39 & 3,56 \\
5 & S5 & 3,64 & 3,69 \\
6 & S6 & 3,89 & 3,79 \\
7 & S7 & 3,79 & 3,76 \\
8 & S8 & 3,46 & 3,45 \\
9 & S9 & 3,52 & 3,70 \\
10 & S10 & 3,56 & 3,60 \\
& Rata-rata & 3,55 & 3,68 \\
\hline
\end{tabular}

Dari Tabel 2 jika digambar dengan diagram maka seperti pada Gambar 2. 


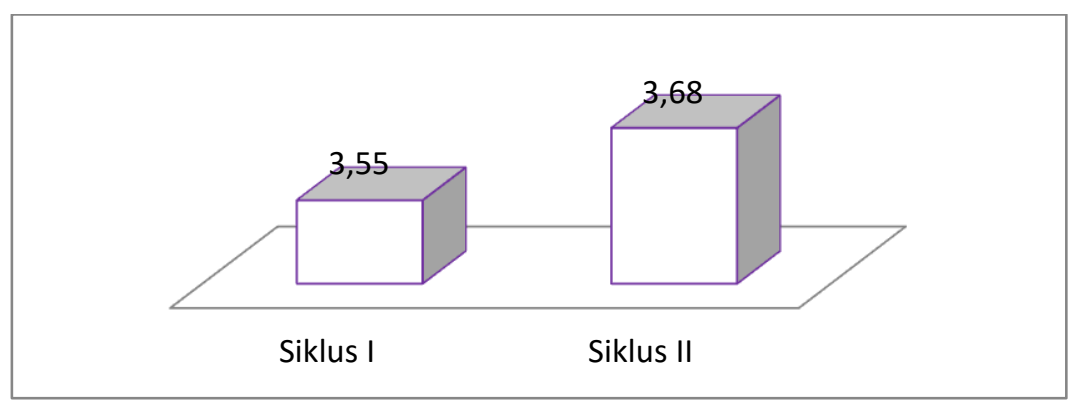

Gambar 2. Hasil penilaian PBM di kelas siklus I dan siklus II

Dari Gambar 2 dapat dilihat bahwa telah terjadi kenaikan nilai yang didapat guru dalam pelaksanaan pembelajaran di kelas dari siklus I ke siklus II. Hal ini menunjukkan adanya peningkatan kemampuan guru dalam pelaksanaan pembelajaran di kelas. Dengan demikian maka dapat disimpulkan bahwa telah terjadi peningkatan nilai yang diperoleh guru baik pada penyusunan RPP maupun pelaksanaan pembelajaran di kelas dan berarti telah terjadi peningkatan kemampuan guru dalam menyusun RPP maupun pelaksanaan pembelajaran di kelas.

\section{KESIMPULAN}

Berdasarkan hasil analisis data maka dapat disimpulkan sebagai berikut: 1) Kemampuan guru dalam menyusun RPP masih belum optimal; 2)Hasil pengamatan pada siklus II menunjukkan adanya peningkatan/ perbaikan kemampuan guru baik dalam menyusun RPP maupun dalam pelaksanaannya di kelas. Kesulitan- kesulitan yang dijumpai pada siklus I sudah dapat diatasi dan 3)Pelaksanaan supervisi klinis dapat meningkatkan kemampuan guru dalam menyusun dan merencanakan pembelajaran.

\section{REKOMENDASI}

Rekomendasi dari penelitian ini adalah waktu melakukan pembimbingan hendaknya dicari waktu yang luang dan pertemuan yang teratur supaya proses pembimbingan berjalan lebih baik.

\section{UCAPAN TERIMAKASIH}

Penulis mengucapan terima kasih kepada guru SD Negeri 3 Picungremuk Kota Tasikmalaya yang telah mendukung terhadap pelaksanaan penelitian ini.

\section{DAFTAR PUSTAKA}

Manullang, M. (1992). Dasar-dasar Manajemen. Jakarta: Ghalia Indonesia

Mulyasa. (2006). Menjadi Guru Profesional Menciptakan Pembelajaran Kreatif dan Menyenangkan. Bandung: Penerbit PT Remaja Rosdakarya.

Purwanto, N. (2006). Psikologi Pendidikan. Bandung: PT Remaja Rosdakarya.

Sahertian, A. P . (2008). Konsep Dasar dan Teknik Supervisi. Jakarta : Penerbit Rineka Cipta.

Sopiah, E, S., Effendi, A., \& Sunaryo, Y. (2020). Analisis Kemampuan Berpikir Kreatif Matematis Siswa Kelas VIII pada Materi Sistem Persamaan Linear Dua Variabel (SPLDV). J-KIP (Jurnal Keguruan dan IImu Pendidikan), 1 (2), 1-10.

Yamin, M. (2006). Profesionalisasi Guru dan Implementasi Kurikulum Berbasis Kompetensi. Jakarta: Gaung Persada. 